\title{
Pengembangan Media Pembelajaran Interaktif Berbentuk Android Packaging Kit (APK) pada Materi Virus
}

\section{Ridha Khairini' ${ }^{*}$, Relsas Yogica ${ }^{2}$}

${ }^{1,2}$ Jurusan Biologi, Universitas Negeri Padang, Padang, Indonesia

\section{A R T I C L E I N F O}

\section{Article history:}

Received August 04, 2021

Revised August 07, 2021

Accepted September 30, 2021

Available online October 25, 2021

Kata Kunci:

Validitas, Media Pembelajaran, Android

Keywords:

Validation, Learning Media, Android

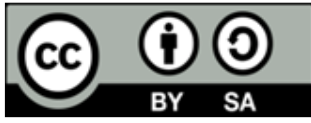

This is an open access article under the CC BY-SA license.

Copyright (C) 2021 by Author. Published by Universitas Pendidikan Ganesho.

\begin{abstract}
A B S T R A K
Pembelajaran abad-21 menuntut para pendidik untuk dapat mengembangkan berbagai media pembelajaran berbasis teknologi. Hanya saja kenyataan di lapangan menunjukkan bahwa tidak semua guru mampu mengikuti perkembangan teknologi. Tujuan penelitian ini yakni untuk menghasilkan produk berupa media pembelajaran interaktif berbentuk android packaging kit pada materi virus. Penelitian ini tergolong ke dalam penelitian pengembangan yang dikembangkan dengan menggunakan model IDI. Subjek yang terlibat dalam penelitian ini yakni siswa sekolah menengah atas, guru, serta 2 orang dosen. Pengumpulan data dalam penelitian dilakukan dengan menggunakan metode observasi, wawancara, dan angket. Instrumen penelitian yang digunakan yakni berupa kuesioner uji validitas. Analisis data hasil penelitian dilakukan dengan menentukan skor setiap validator dengan cara menjumlahkan setiap skor pada setiap indikator dan terakhir Memberikan penilaian valid menggunakan prosedur penilaian persentase. Hasil penelitian menunjukkan bahwa pada aspek kelayakan isi, nilai validitas media mencapai skor $84,52 \%$ dengan katerogi valid. Selanjutnya, pada aspek kebahasaan hasil nilai validitas media yakni $85,41 \%$ dengan kategori valid, aspek sajian memperoleh nilai validitas sebesar $85 \%$ dengan kategori valid, dan aspek kegrafikan memperoleh nilai validitas $90,74 \%$ dengan kategori sangat valid. Berdasarkan validitas keempat aspek tersebut, maka dapat diketahui nilai rata-rata validitas, yakni sebesar $86,41 \%$ dan berada dalam kategori valid. Berdasarkan hasil tersebut dapat disimpulkan bahwa media pembelajaran berbentuk android packaging kit (apk) layak untuk digunakan berdasarkan pertimbangan validator.
\end{abstract}

\begin{abstract}
A B S T R A C T
21st century learning requires educators to be able to develop a variety of technology-based learning media. It's just that the reality on the ground shows that not all teachers are able to keep up with technological developments. The purpose of this research is to produce products in the form of interactive learning media in the form of android packaging kits on virus material. This research belongs to development research developed using the IDI model. The subjects involved in this study were high school students, teachers and 2 lecturers. Data collection in research is done using observation methods, interviews, and questionnaires. The research instrument used is in the form of a quisioner validity test. Analysis of the data of the results of the study is done by determining the score of each validator by summing each score on each indicator, and finally providing a valid assessment using a percentage assessment procedure. The results showed that in the aspect of eligibility the content of the media validity value reached a score of $84.52 \%$ with a valid katerogi. Furthermore, in the language aspect the results of media validity values are $85.41 \%$ with valid categories, the present aspect obtains a validity value of $85 \%$ with valid categories, and the aspect of radiography obtains a validity value of $90.74 \%$ with a very valid category. Based on the validity of these four aspects, it can be known the average value of validity, which is $86.41 \%$ and is in the valid category. So based on these results it can be concluded that the learning media in the form of android packaging kit is suitable for use based on the consideration of validators.
\end{abstract}




\section{PENDAHULUAN}

Proses pembelajaran merupakan interaksi antara guru dan peserta didik, peserta didik dan lingkungannya untuk mencapai tujuan pembelajaran (Hazmi, 2019; Mansyur, 2020; Tafonao, 2018). Melalui kegiatan pembelajaran guru dapat menyampaikan berbagai informasi kepada siswa dengan cara menciptakan lingkungan belajar yang bervariasi, sehingga proses belajar lebih optimal (Kirom, 2017; Kuswanto, 2020). Di dalam diri peserta didik terjadi proses belajar yang sesuai dengan perkembangan serta lingkungannya, sehingga peserta didik dapat belajar dari berbagai sumber belajar dan media pembelajaran yang ada di lingkungannya (Wulandari, 2020). Media dan sumber belajar memiliki peran penting dalam proses pembelajaran, hal ini dikarenakan media dapat membantu peserta didik memahami informasi yang akan disampaikan (Angriani et al., 2020; Utami \& Zanah, 2021). Media menjadi salah satu perangkat pembelajaran yang dapat memberikan stimulus, memberikan pengalaman pada peserta didik serta membantu melakukan pengamatan yang sama pada peserta didik, sehingga peserta didik memiliki pemahaman yang sama terhadap informasi yang disampaikan (Menrisal \& Putri, 2018).

Media pembelajaran pada pendidikan abad ke-21 merupakan media yang memanfaatkan teknologi sebagai salah satu media untuk belajar (Anggraeni \& Sole, 2018). Pendidikan modern saat ini memanfaatkan keberadaan teknologi informasi dan komunikasi sebagai salah satu sarana baik berupa media dan sumber belajar untuk memperoleh ilmu pengetahuan dengan jangkauan yang sangat luas dan biaya yang relatif murah (Mulyono \& Ampo, 2021; Mushfi, 2019). Media pembelajaran yang diintegrasikan dengan penggunaan teknologi informasi memiliki tujuan untuk memberikan kemudahan pada guru ataupun peserta didik (Tahel \& Ginting, 2019). Selain itu, pemanfaatan media berbasis teknologi juga dapat memberikan nilai tambah dalam proses pembelajaran karena berkaitan dengan semakin tingginya kebutuhan informasi yang tidak seluruhnya bisa didapat di lingkungan sekolah (Wijaya \& Agus, 2018). Hanya saja kenyataan di lapangan menunjukkan bahwa tidak semua guru mampu memanfaatkan teknologi sebagai media pembelajaran (Astuti et al., 2018; Irvani et al., 2020; Rahim et al., 2019). Guru hanya berfokus pada penggunaan media cetak, yang cenderung kurang efektif dan efisien. Hal ini sejalan dengan hasil obeservasi yang telah dilakukan di kelas X SMAN 8 Padang. Hasil observasi menunjukkan bahwa proses pembelajaran biologi dilakukan dengan menggunakan media pembelajaran berupa media cetak, yaitu buku teks dan lembar kerja peserta didik (LKPD) serta media lainnya seperti video pembelajaran dan microsoft power point. Namun, dalam pelaksanaannya media pembelajaran tersebut memiliki beberapa kendala untuk digunakan, seperti kurangnya jumlah LCD Projector yang ada di sekolah, sehingga peserta didik hanya dibekali dengan buku teks dan LKPD. Kendala lainnya dalam proses pembelajaran biologi adalah kurangnya motivasi peserta didik dalam membaca buku teks karena dianggap kurang menarik bagi peserta didik.

Kurangnya kemampuan guru dalam menyediakan media yang sesuai dengan kebutuhan siswa kemudian berdampak pada rendahnya kemampuan peserta didik dalam memahami berbagai materi biologi. Hasil pemahaman materi siswa menunjukkan bahwa $70 \%$ peserta didik menyatakan merasa kesulitan untuk memahami materi virus, 30\% untuk materi ruang lingkup biologi, $16 \%$ untuk materi keanekaragaman hayati, 38\% untuk materi sistem klasifikasi makhluk hidup. Materi virus dianggap sukar dipahami karena terdapat banyak istilah asing, materi rumit, media pembelajaran yang sulit dipahami, dan objek yang tidak bisa diamati secara langsung. Selain itu, peserta didik juga belum didukung oleh media pembelajaran yang sesuai dengan pembelajaran abad ke-21. Untuk mengatasi permasalahan tersebut maka dibutuhkan suatu media yang dapat memenuhi kebutuhan siswa, serta dapat sejalan dengan perkembangan teknologi abad 21. Salah satu hasil dari perkembangan teknologi yang banyak digunakan di abad ke-21 adalah Smartphone (ponsel pintar) dengan sistem operasi android. Android merupakan sebuah sistem operasi pada perangkat mobile berbasis linux yang mencakup sistem operasi, middleware, dan aplikasi. Android memberikan kesempatan bagi para pengembang untuk menciptakan aplikasi mereka (Brucles et al., 2019; Erri Wahyu Puspitarini, 2016; Voutama \& Novalia, 2021). Smartphone menjadi salah satu kebutuhan tersier yang sudah diutamakan oleh semua kalangan, baik orang dewasa maupun anak-anak. Penggunaan smartphone android sebagai media pembelajaran dapat meningkatkan prestasi kognitif dan meningkatkan motivasi peserta didik. Android dapat menghadirkan suasana baru dalam pembelajaran (Ardiansyah \& Nana, 2020; Hidayati \& Aslam, 2021). Selain itu, media android juga dapat meningkatkan motivasi untuk mempelajari materi yang ada dengan proses yang cepat karena terdapat beberapa kelebihan, yaitu tampilan desain yang menarik, baik dari segi tulisan, warna, animasi dan gambar, serta dapat digunakan secara mandiri baik di sekolah maupun di luar sekolah (Erfan et al., 2020; Muyaroah \& Fajartia, 2017; Negara et al., 2019; Rahmat et al., 2019).

Beberapa penelitian yang telah dilakukan sebelumnya menunjukkan bahwa bahwa terdapat hasil yang positif pada kemampuan memahami konsep dan terdapat respon yang sangat baik dari peserta didik terhadap penggunaan android sebagai media pembelajaran (Widiastika et al., 2020). Penelitian selanjutnya juga mengungkapkan bahwa penggunaan android sebagai media pembelajaran dapat 
digunakan sebagai sumber belajar jarak jauh, karena bisa digunakan dimana saja dan kapan saja serta bisa digunakan secara berulang-ulang bagi peserta didik tingkat SMA/MA (Saputra et al., 2020). Penelitian lainnya juga mengungkapkan bahwa penggunaan android sebagai media pembelajaran bersifat fleksibel karena dapat digunakan di dalam maupun di luar kelas (Adhi et al., 2017). Berdasarkan beberapa penelitian yang telah dilakukan oleh peneliti sebelumnya maka dapat dikatakan bahwa penggunaan smartphone android dalam proses pembelajaran dapat meningkatkan hasil belajar serta motivasi belajar siswa karena sangat mudah digunakan. Hanya saja pada penelitian sebelumnya belum terdapat kajian mengenai pengembangan media Interaktif Berbentuk Android Packaging Kit (APK) pada materi virus. Oleh karena itu, penelitian ini difokuskan pada kajian tersebut dengan tujuan untuk menghasilkan produk berupa media pembelajaran interaktif berbentuk android packaging kit pada materi virus.

\section{METODE}

Penelitian Penelitian ini merupakan jenis penelitian pengembangan, yang dikembangkan menggunakan model Instructional Development institute (IDI). Terdapat tiga tahapan dari model pengembangan ini, yaitu tahap pendefinisian (define), tahap pengembangan (develop), dan tahap penilaian (evaluate). Tahap pendefinisian bertujuan untuk mendefinisikan dan menetapkan hal dibutuhkan dalam proses pembelajaran.Pada tahap ini dilakukan berbagai analisis yaitu analisis kurikulum, analisis media pembelajaran, analisis peserta didik, dan analisis konsep. Tahap selanjutnya adalah tahap pengembangan. Tahap ini terdiri dari perancangan produk dan pengujian validitas produk. Dan tahap terakhir adalah tahap penilaian yang tidak dapat dilaksanakan karena keterbatasan penelitian. Subjek yang terlibat dalam penelitian ini yakni siswa kelas X SMA N 8 Padang, 1 orang guru biologi, dan 2 orang dosen dari Jurusan Biologi FMIPA UNP. Pengumpulan data dalam penelitian dilakukan dengan menggunakan metode observasi, wawancara, dan angket. Dengan instrumen berupa kuesioner dilakukan uji validitas. Media pembelajaran berbentuk APK tentang materi virus diuji menggunakan angket validitas yang berguna untuk mengevaluasi media pembelajaran. Angket uji validitas diisi oleh 3 orang validator yaitu dua orang dosen dari jurusan biologi FMIPA UNP dan satu orang guru biologi di SMAN 8 Padang. Angket disusun berdasarkan skala Likert. Setelah data validitas didapatkan, selanjutnya dilakukan analisis angket pada uji validitas yang sebelumnya sudah diisi oleh validator. Analisis data dilakukan dengan menentukan skor dari setiap validator dengan cara menjumlahkan setiap skor pada setiap indikator, dan akhirnya memberikan penilaian valid menggunakan prosedur penilaian persentase.

\section{HASIL DAN PEMBAHASAN}

Hasil

Penelitian pengembangan media dilakukan dalam tiga tahap pengembangan. Adapun hasil dari tiap tahap pengembangan adalah sebagai berikut. Tahap pengembangan yang pertama yakni tahap pendefinisian (define). Tahap pendefinisian (define) merupakan tahapan untuk mengidentifikasi kebutuhan dalam pembelajaran. Pada tahap ini dilakukan berbagai analisis yaitu analisis kurikulum, analisis media pembelajaran, dan analisis peserta didik. Berdasarkan hasil wawancara pada guru biologi dan memberikan lembar observasi kepada peserta didik kelas X di SMAN 8 Padang, maka didapatkan hasil bahwa materi virus merupakan salah satu materi yang sulit dipahami oleh peserta didik dengan persentase $70 \%$. Sulitnya siswa dalam memahami materi virus disebabkan karena materi virus dianggap sebagai materi yang rumit, terdapat banyak istilah asing, serta banyak objek yang sulit untuk diamati. Berdasarkan permasalahan tersebut maka siswa membutuhkan media yang dapat membantu peserta didik dalam memahaminya.

Selanjutya, pada hasil analisis media pembelajaran ditemukan bahwa dalam proses pembelajaran biologi di SMAN 8 Padang yaitu berupa buku teks, lembar kerja peserta didik, microsoft power point, dan video pembelajaran. Namun dalam pelaksanaannya, media berupa microsoft power point dan video pembelajaran jarang digunakan karena terbatasnya sarana dan prasarana yang ada di sekolah, Hal ini mengakibatkan peserta didik lebih sering menggunakan buku teks dalam pembelajaran. Berdasarkan hasil wawancara dengan guru biologi kelas X di SMAN 8 didapatkan fakta bahwa peserta didik kurang termotivasi untuk menggunakan buku teks karena buku yang terlihat monoton. Peserta didik membutuhkan sumber belajar lain yang dapat dipelajari secara mandiri dengan kriteria media pembelajaran yang dapat memberikan materi yang lengkap, menggunakan bahasa yang mudah dimengerti, disertai dengan gambar, bersifat praktis, dan dapat menguji kemampuan peserta didik akan materi virus. Media pembelajaran interaktif berbentuk APK merupakan salah satu media pembelajaran berbasis teknologi yang sesuai dengan kebiasaan peserta didik pada pembelajaran abad ke-21 dan bersifat praktis karena dapat diakses dengan mudah. 
Setelah didapatkan hasil analisis kebutuhan pembelajaran siswa, maka penelitian dilanjutkan pada tahap kedua, yakni tahap pengembangan media (develop). Pada tahap pengembangan (develop) dilakukan perancangan dan uji validitas untuk media pembelajaran. Produk berupa media pembelajaran berbentuk APK dibuat dengan menggunakan aplikasi microsoft powerpoint, iSpring Suite 10, Website 2 APK Builder Pro. Perancangan diawali dengan membuat desain tampilan media, mengumpulkan materi, menyusun soal-soal, serta membuat media pembelajaran dengan materi virus. Pengembangan media dilakukan dengan memerhatikan masukan dari validator. Adapun hasil pengembangan media berdasarkan masukan dari validator dapat dilihat pada gambar 1 .
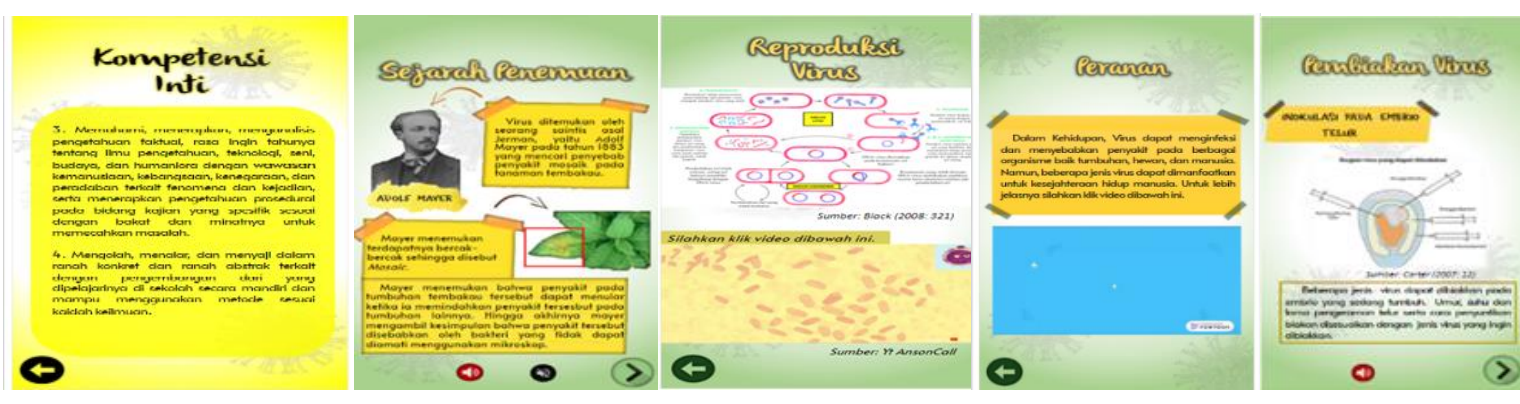

Gambar 1. Hasil Pengembangan Media

Setelah media selesai dikembangkan maka penelitian kemudian dilanjutkan pada tahap ketiga, yakni tahap penilaian (evaluate). Penilaian dilakukan dengan menguji validitas media yang telah dikembangkan. Uji validitas media pembelajaran dilakukan oleh tiga orang validator, yaitu dua orang dosen dari Jurusan Biologi FMIPA UNP dan satu orang guru biologi di SMAN 8 Padang. Adapun hasil penilaian validitas berdasarkan aspek kelayakan isi, kebahasaan, sajian, dan kegrafikaan. Hasil dari uji validitas dapat dilihat pada Tabel 1 .

Tabel 1. Hasil Validasi

\begin{tabular}{lccccccc}
\hline $\begin{array}{c}\text { Aspek } \\
\text { Penilaian }\end{array}$ & I & II & III & $\begin{array}{c}\text { Jumlah } \\
\text { Skor }\end{array}$ & $\begin{array}{c}\text { Skor } \\
\text { Maksimal }\end{array}$ & $\begin{array}{c}\text { Nilai } \\
\text { Validitas } \\
\text { (\%) }\end{array}$ & Kategori \\
\hline Kelayakan isi & 27 & 23 & 21 & 71 & 84 & 84,52 & Valid \\
Kebahasaan & 14 & 12 & 15 & 41 & 48 & 85,41 & Valid \\
Sajian & 19 & 15 & 17 & 51 & 60 & 85 & Valid \\
Kegrafikaan & 33 & 29 & 36 & 98 & 108 & 90,74 & Sangat valid \\
Total & & & & 262 & 300 & 345,86 & Valid \\
Rata-rata & & & & 65,5 & 75 & 86,41 & \\
\hline
\end{tabular}

Berdasarkan tabel 1 dapat diketahui bahwa pada aspek kelayakan isi nilai validitas media mencapai skor $84,52 \%$ dengan katerogi valid. Selanjutnya, pada aspek kebahasaan hasil nilai validitas media yakni $85,41 \%$ dengan kategori valid, aspek sajian memperoleh nilai validitas sebesar $85 \%$ dengan kategori valid, dan aspek kegrafikan memperoleh nilai validitas 90,74\% dengan kategori sangat valid. Berdasarkan validitas keempat aspek tersebut, maka dapat diketahui bahwa nilai rata-rata validitas sebesar $86,41 \%$ dan berada dalam kategori valid.

\section{Pembahasan}

Hasil analisis data menunjukkan bahwa media pembelajaran interaktif berbentuk android packaging kit (APK) pada materi virus berada dalam ketegori valid, sehingga sangat layak untuk dikembangkan dan dibelajarkan kepada siswa. Terdapat beberapa faktor yang memengaruhi keberhasilan pengembangan media pembelajaran interaktif berbentuk android packaging kit (APK) pada materi virus sebagai berikut. Faktor pertama, yakni media yang dikembangkan telah sesuai dengan kebutuhan pembelajaran siswa. Kebutuhan siswa dalam proses pembelajaran abad-21 yakni berupa media pembelajaran yang mampu membantu siswa untuk memahami penggunaan teknologi (Habib et al., 2020; Puspitasari, 2019; Robbia \& Fuadi, 2020). Seperti yang telah diketahui bersama bahwa handphone android 
merupakan salah satu contoh hasil perkembangan teknologi. Di masa kini android tidak hanya dapat digunakan untuk berkomunikasi jarak jauh, melainkan juga dapat digunakan untuk mencari informasi dan berbagai bahan belajar (Astini, 2020; Batubara, 2018; Kuswanto \& Radiansah, 2018). Selain itu, di era modern seperti saat ini android menjadi salah satu media yang sangat praktis untuk digunakan. Melalui aplikasi android, siswa akan dapat belajar sambil bermain dan memaksimalkan kemampuannya dalam penggunaan teknologi (Ayuningrum \& Afif, 2021; Guterres et al., 2018).

Faktor kedua, yakni isi materi yang disajikan telah layak dan sesuai dengan tujuan pembelajaran. Hal ini sejalan dengan hasil uji kelayakan isi media pembelajaran interaktif berbentuk APK tentang materi virus memiliki nilai validitas sebesar $84,52 \%$ dengan kategori valid. Hal ini menunjukkan bahwa media pembelajaran interaktif berbentuk APK tentang materi virus telah sesuai dengan Kurikulum 2013 dan tuntutan Kompetensi Dasar (KD) serta Kompetensi Inti (KI). Kebutuhan peserta didik akan media dapat didasarkan pada tuntutan kurikulum, sehingga penyusunan materi dalam suatu media pembelajaran harus berpedoman pada Kompetensi Dasar dan Kompetensi Inti atau sesuai dengan tujuan pembelajaran (Putra et al., 2021).

Faktor ketiga, yakni bahasa yang digunakan dalam media merupakan bahasa Indonesia yang mudah dipahami oleh siswa. Penggunaan bahasa menjadi salah satu aspek penting yang harus diperhatikan dalam penyusunan sebuah media (Khulsum et al., 2019; Sukirman, 2020). Penggunaan bahasa yang baik akan dapat membantu siswa untuk memahami isi media dengan mudah, sehingga tidak terjadi miskonsepsi (Anesia et al., 2018; Ramdani et al., 2020). Bahasa yang digunakan pada suatu media pembelajaran adalah bahasa yang berhubungan dengan materi yang dibahas serta mudah dicerna dan mudah dipahami (Fachri et al., 2021).

Faktor keberhasilan keempat, yakni media yang dikembangan memiliki penyajian yang menarik. Penyajian yang menarik artnya bahwa media yang dikembangkan telah sesuai dengan tujuan pembelajaran, memiliki urutan yang sistematis, dapat memberikan motivasi, serta sudah memiliki informasi yang lengkap. Media yang baik merupakan media yang sesuai dengan kebutuhan peserta didik serta media yang dapat meningkatkan motivasi peserta didik untuk mempelajari materi dengan baik (Sulfemi, 2019; Tafonao, 2018).

Faktor penentu keberhasilan kelima, yakni media yang dikembangkan telah memenuhi kualitas kegrafikan yang baik. Kegrafikan dalam media, yakni berupa ukuran tulisan yang tepat dan jelas, tata letak, ilustrasi dan video pembelajaran yang mudah untuk dipahami, serta desain tampilan yang sesuai dengan kebutuhan peserta didik. Desain serta berbagai macam gambar yang ditampilkannya, yang berupa sebuah gambar akan menimbulkan ketertarikan tersendiri bagi peserta didik untuk memahami alasan mengapa gambar tersebut ditampilkan (Samala et al., 2019; Wijayanti \& Relmasira, 2019). Dalam suatu media pembelajaran, kemudahan penggunaan media merupakan salah satu karakteristik media pembelajaran yang baik untuk digunakan. Hasil yang diperoleh dalam penelitian ini sejalan dengan hasil penelitian sebelumnya yang juga mengungkapkan bahwa terdapat hasil yang positif pada kemampuan memahami konsep dan terdapat respon yang sangat baik dari peserta didik terhadap penggunaan android sebagai media pembelajaran (Widiastika et al., 2020). Penelitian selanjutnya juga mengungkapkan bahwa penggunaan android sebagai media pembelajaran dapat digunakan sebagai sumber belajar jarak jauh, karena bisa digunakan dimana saja dan kapan saja serta bisa digunakan secara berulang-ulang bagi peserta didik tingkat SMA/MA (Saputra et al., 2020). Penelitian lainnya juga mengungkapkan bahwa penggunaan android sebagai media pembelajaran bersifat fleksibel karena dapat digunakan di dalam maupun di luar kelas (Adhi et al., 2017). Berdasarkan hasil tersebut dapat dikatakan bahwa penggunaan android sebagai media pembelajaran sangatlah sesuai kususnya dalam proses pembelajaran abad-21.

\section{SIMPULAN}

Dari penelitian ini, maka dapat disimpulkan bahwa media pembelajaran interaktif berbentuk android packaging kit (apk) pada materi virus telah berhasil dikembangkan. Media pembelajan yang dikembangkan memilki nilai validitas yang tergolong tinggi, sehingga dapat dikategorikan layak untuk digunakan berdasarkan pertimbangan para ahli. Saran selanjutnya, guru dan peserta didik disarankan untuk dapat memanfaatkannya sebagai media alternatif dalam belajar biologi pada materi virus. Pengembangan media serupa pada materi biologi lainnya juga disarankan untuk dikembangkan, sehingga dapat membantu guru dan peserta didik dalam memahami materi biologi.

\section{DAFTAR RUJUKAN}

Adhi, S., Marhadini, K., Akhlis, I., \& Sumpono, I. (2017). Pengembangan Media Pembelajaran Berbasis Android pada Materi Gerak Parabola untuk Siswa SMA. UPEJ Unnes Physics Education Journal, 
6(3), 38-43. https://doi.org/10.15294/upej.v6i3.19315.

Anesia, R., Anggoro, B. S., \& Gunawan, I. (2018). Pengembangan Media Komik Berbasis Android pada Pokok Bahasan Gerak Lurus. Indonesian Journal Science and Mathematics Education, 1(2). https://doi.org/10.24042/ijsme.v1i2.2774.

Anggraeni, D. M., \& Sole, F. B. (2018). E-Learning Moodle, Media Pembelajaran Fisika Abad 21. Jurnal Penelitian Dan Pengkajian Ilmu Pendidikan: E-Saintika, 1(2), 57. https://doi.org/10.36312/esaintika.v1i2.101.

Angriani, A. D., Kusumayanti, A., \& Nur, F. (2020). Pengembangan Media Pembelajaran MathSC Berbasis Android Menggunakan App Inventor 2 pada Materi Barisan dan Deret Aritmatika. Jurnal Cendekia: Jurnal Pendidikan Matematika, 426-938. https://doi.org/10.31004/cendekia.v4i2.322.

Ardiansyah, A. A., \& Nana, N. (2020). Peran Mobile Learning sebagai Inovasi dalam Meningkatkan Hasil Belajar Siswa pada Pembelajaran di Sekolah. Indonesian Journal Of Educational Research and Review, 3(1), 47. https://doi.org/10.23887/ijerr.v3i1.24245.

Astini, N. K. suni. (2020). Tantangan dan Peluang Pemanfaatan Teknologi Informasi dalam Pembelajaran Online Masa Covid-19. Cetta: Jurnal Ilmu Pendidikan, 3(2), 241-255. https://doi.org/10.37329/cetta.v3i2.452.

Astuti, I. A. D., Dasmo, D., \& Sumarni, R. A. (2018). Pengembangan Media Pembelajaran Berbasis Android dengan Menggunakan Aplikasi Appypie di SMK Bina Mandiri Depok. Jurnal Pengabdian Kepada Masyarakat, 24(2), 695. https://doi.org/10.24114/jpkm.v24i2.10525.

Ayuningrum, D., \& Afif, N. (2021). Aplikasi Berbasis Android dalam Meningkatkan Kognitif Anak Usia Dini. Journal of Islamic Education, 3(2), 169-184. https://doi.org/10.51275/alim.v3i2.216.

Batubara, H. H. (2018). Pengembangan Media Pembelajaran Matematika Berbasis Android untuk Siswa SD/MI. Muallimuna: Jurnal Madrasah Ibtidaiyah, 3(1), 12. https://doi.org/10.31602/muallimuna.v3i1.952.

Brucles, L. D., Kurniawan, R., \& Adrianto, S. (2019). Aplikasi Panduan Praktis Obat Herbal untuk Penyakit Dalam Berbasis Platform Android. Jurnal Informatika, 10(2), 40. https://doi.org/10.36723/juri.v10i2.114.

Erfan, M., Widodo, A., Umar, U., Radiusman, R., \& Ratu, T. (2020). Pengembangan Game Edukasi "Kata Fisika" Berbasis Android untuk Anak Sekolah Dasar pada Materi Konsep Gaya. Lectura: Jurnal Pendidikan, 11(1), 31-46. https://doi.org/10.31849/lectura.v11i1.3642.

Erri Wahyu Puspitarini, D. W. P. A. P. N. (2016). Game Edukasi Berbasis Android sebagai Media Pembelajaran untuk Anak Usia Dini. J I M P - Jurnal Informatika Merdeka Pasuruan, 1(1), 46-58. https://doi.org/10.37438/jimp.v1i1.7.

Fachri, A. Z., Ajie, H., \& Oktaviani, V. (2021). Pengembangan Video Pembelajaran pada Mata Pelajaran Dasar Desain Grafis Kelas X SMK Negeri 40 Jakarta. Pinter : Jurnal Pendidikan Teknik Informatika Dan Komputer, 5(2), 50-55. https://doi.org/10.21009/pinter.5.2.8.

Guterres, I. K. N. P., Sudarti, S., M, M., \& Putra, P. D. A. (2018). Pengembangan Media Pembelajaran Ular Tangga Berbasis Android pada Pokok Bahasan Gejala Pemanasan Global untuk Pembelajaran Fisika di SMA. Jurnal Pembelajaran Fisika, 7(1), 54. https://doi.org/10.19184/jpf.v7i1.7225.

Habib, A., Astra, I. M., \& Utomo, E. (2020). Kebutuhan Multimedia Interaktif bagi Guru dan Siswa Sekolah Dasar Pembelajaran Sesuai Konteks Pembelajaran Abad 21. Jurnal Riset Teknologi Dan Inovasi Pendidikan, 3(1), 25-35. http://journal.rekarta.co.id/index.php/jartika/article/view/319/306.

Hazmi, N. (2019). Tugas Guru dalam Proses Pembelajaran. Journal of Education and Instruction (JOEAI), 2(1), 56-65. https://doi.org/10.31539/joeai.v2i1.734.

Hidayati, I. D., \& Aslam, A. (2021). Efektivitas Media Pembelajaran Aplikasi Quizizz secara Daring terhadap Perkembangan Kognitif Siswa. Jurnal Pedaagogi Dan Pembelajaran, 4(1). https://doi.org/10.23887/jp2.v4i2.37038.

Husna Arsyah, R., Ramadhanu, A., \& Pratama, F. (2019). Perancangan dan Pembuatan Media Pembelajaran Berbasis Android Mata Pelajaran Sistem Komputer ( Studi Kasus Kelas X TKJ SMK Adzkia Padang ). Jurnal Teknologi Dan Sistem Informasi Bisnis, 1(2), 31-38. https://doi.org/10.47233/jteksis.v1i2.49.

Irvani, A. I., Warliani, R., \& Amarulloh, R. R. (2020). Pelatihan Pemanfaatan Teknologi Informasi Komunikasi sebagai Media Pembelajaran. Jurnal PkM MIFTEK, 1(1), 29-41. https://doi.org/10.33364/miftek/v.1-1.35.

Khulsum, U., Hudiyono, Y., \& Sulistyowati, E. D. (2019). Pengembangan Bahan Ajar Menulis Cerpen dengan Media Storyboard pada Siswa Kelas X SMA. Diglosia: Jurnal Kajian Bahasa, Sastra, Dan Pengajarannya, 1(1), 1-12. https://doi.org/10.30872/diglosia.v1i1.4.

Kirom, A. (2017). Peran Guru dan Peserta Didik dalam Proses Pembelajaran Berbasis Multikultural. Jurnal 
Pendidikan Agama Islam, 3(1), 69-80. https://jurnal.yudharta.ac.id/v2/index.php/pai/article/view/893.

Kuswanto, J. (2020). Media Pembelajaran Berbasis Android Mata Pelajaran Desain Grafis Kelas X. Edutic $\begin{array}{llll}\text { Scientific Journal of Informatics } & \text { Education, }\end{array}$ https://doi.org/10.21107/edutic.v6i2.7073.

Kuswanto, J., \& Radiansah, F. (2018). Media Pembelajaran Berbasis Android pada Mata Pelajaran Sistem Operasi Jaringan Kelas XI. Jurnal Media Infotama, 14(1). https://doi.org/10.37676/jmi.v14i1.467.

Mansyur, A. R. (2020). Dampak COVID-19 terhadap Dinamika Pembelajaran di Indonesia. Education and Learning Journal, 1(2), 113. https://doi.org/10.33096/eljour.v1i2.55.

Menrisal, M., \& Putri, H. M. (2018). Perancangan dan Pembuatan Media Pembelajaran Berbasis Android Mata Pelajaran Pemrograman Dasar. Jurnal Pti (Pendidikan dan Teknologi Informasi), 5(2), 21-30. https://doi.org/10.35134/jpti.v5i2.10.

Mulyono, \& Ampo, I. (2021). Pemanfaatan Media dan Sumber Belajar Abad 21. Paedagogia: Jurnal Pendidikan, 9(2), 93-112. https://doi.org/10.24239/pdg.vol9.iss2.72.

Mushfi, M. (2019). Implementasi Media Pembelajaran Berbasis Teknologi Informasi dan Komunikasi dalam Distance Learning. Tarbiyatuna: Kajian Pendidikan Islam, 3(1), 29. https://doi.org/10.29062/tarbiyatuna.v3i1.198.

Muyaroah, S., \& Fajartia, M. (2017). Pengembangan Media Pembelajaran Berbasis Android dengan Menggunakan Aplikasi Adobe Flash CS 6 pada Mata Pelajaran Biologi Abstrak. Innovative Journal of Curriculum and Educational Technology, 6(2), 79-83. https://doi.org/10.15294/IJCET.V6I2.19336.

Negara, H. R. P., Syaharuddin, S., Kurniawati, K. R. A., Mandailina, V., \& Santosa, F. H. (2019). Meningkatkan Minat Belajar Siswa melalui Pemanfaatan Media Belajar Berbasis Android Menggunakan Mit App Inventor. Jurnal Pengabdian Masyarakat Berkemajuan, 2(2), 42. https://doi.org/10.31764/jpmb.v2i2.887.

Puspitasari. (2019). Penerapan Media Pembelajaran Fisika Menggunakan Modul Cetak dan Modul Elektronik Pada Siswa SMA. Jurnal Pendidikan Fisika, 7(1), 17-25. http://journal.uinalauddin.ac.id/indeks.php/PendidikanFisika.

Putra, I. P. D. P., Priantini, D. M. O., Made, A., \& Winaya, I. M. A. (2021). Pengembangan Video Animasi Pembelajaran Interaktif Berbasis Tri Hita Karana untuk Meningkatkan Hasil Belajar Siswa SD. Jurnal Ilmiah Pendidikan Citra Bakti, 8(2), 325-338. https://doi.org/10.38048/jipcb.v8i2.344.

Rahim, F. R., Suherman, D. S., \& Murtiani, M. (2019). Analisis Kompetensi Guru dalam Mempersiapkan Media Pembelajaran Berbasis Teknologi Informasi Era Revolusi Industri 4.0. Jurnal Eksakta Pendidikan (JEP), 3(2), 133. https: //doi.org/10.24036/jep/vol3-iss2/367.

Rahmat, R. F., Mursyida, L., Rizal, F., Krismadinata, K., \& Yunus, Y. (2019). Pengembangan Media Pembelajaran Berbasis Mobile Learning pada Mata Pelajaran Simulasi Digital. Jurnal Inovasi Teknologi Pendidikan, 6(2), 116-126. https://doi.org/10.21831/jitp.v6i2.27414.

Ramdani, A., Jufri, A. W., \& Jamaluddin, J. (2020). Pengembangan Media Pembelajaran Berbasis Android pada Masa Pandemi Covid-19 untuk Meningkatkan Literasi Sains Peserta Didik. Jurnal Hasil Penelitian Dan Kajian Kepustakaan Di Bidang Pendidikan, Pengajaran Dan Pembelajaran, 6(3), 433. https://doi.org/10.33394/jk.v6i3.2924.

Robbia, A. Z., \& Fuadi, H. (2020). Pengembangan Keterampilan Multimedia Interaktif Pembelajaran IPA untuk Meningkatkan Literasi Sains Peserta Didik di Abad 21. Jurnal Ilmiah Profesi Pendidikan, 5(2), 117-123. https://doi.org/10.29303/jipp.v5i2.125.

Samala, A. D., Fajri, B. R., \& Ranuharja, F. (2019). Desain dan Implementasi Media Pembelajaran Berbasis Mobile Learning Menggunakan Moodle Mobile App. Jurnal Teknologi Informasi Dan Pendidikan, 12(2), 13-19. https://doi.org/10.24036/tip.v12i2.221.

Saputra, G. Y., Harjanto, A., \& Ningsih, Y. A. (2020). Pengembangan Media Pembelajaran Berbasis Android untuk Mata Pelajaran Fisika Materi Pokok Energi di Kelas X IPA 1 SMA Negeri 2 Muara Badak Tahun Ajaran 2019/2020. Journal of Advances in Information and Industrial Technology, 2(2), 1024. https://doi.org/10.52435/jaiit.v2i2.67.

Sukirman, S. (2020). Tes Kemampuan Keterampilan Menulis dalam Pembelajaran Bahasa Indonesia di Sekolah. Jurnal Konsepsi, 9(2), 72-81. https://p3i.my.id/index.php/konsepsi/article/view/42/38.

Sulfemi, W. B. (2019). Model Pembelajaran Kooperatif Mind Mapping Berbantu Audio Visual dalam Meningkatkan Minat, Motivasi, dan Hasil Belajar IPS. Jurnal PIPSI Uurnal Pendidikan IPS Indonesia), 4(1), 13. https://doi.org/10.26737/jpipsi.v4i1.1204.

Tafonao, T. (2018). Peranan Media Pembelajaran dalam Meningkatkan Minat Belajar Mahasiswa. Jurnal Komunikasi Pendidikan, 2(2), 103. https://doi.org/10.32585/jkp.v2i2.113.

Tahel, F., \& Ginting, E. (2019). Perancangan Aplikasi Media Pembelajaran Pengenalan Pahlawan Nasional 
untuk Meningkatkan Rasa Nasionalis Berbasis Android. Jurnal Teknologi Dan Informatika, 09(02), 113-120. http://ojs.palcomtech.ac.id/index.php/teknomatika/article/view/467.

Utami, F. T., \& Zanah, M. (2021). Youtube sebagai Sumber Informasi bagi Peserta Didik di Masa Pandemi Covid-19. Jurnal Sinestesia, 11(1), 78-84. https://doi.org/10.53696/27219283.64.

Voutama, A., \& Novalia, E. (2021). Perancangan Aplikasi M-Magazine Berbasis Android sebagai Sarana Mading Sekolah Menengah Atas. Jurnal Tekno Kompak, 15(1), 104. https://doi.org/10.33365/jtk.v15i1.920.

Widiastika, M. A., Hendracipta, N., \& Syachruroji, A. (2020). Pengembangan Media Pembelajaran Mobile Learning Berbasis Android pada Konsep Sistem Peredaran Darah di Sekolah Dasar. Jurnal Basicedu, 5(1), 47-64. https://doi.org/10.31004/basicedu.v5i1.602.

Wijayanti, W., \& Relmasira, S. C. (2019). Pengembangan Media PowerPoint IPA untuk Siswa Kelas IV SD Negeri Samirono. Jurnal Penelitian Dan Pengembangan Pendidikan, 3(2), 77. https://doi.org/10.23887/jppp.v3i2.17381.

Wulandari, F. (2020). Pemanfaatan Lingkungan sebagai Sumber Belajar Anak Sekolah Dasar. Journal of Educational Review and Research, 3(2), 105. https://doi.org/10.26737/jerr.v3i2.2158. 